\title{
Phytoplankton sinking rate dynamics in the southern Benguela upwelling system
}

\author{
G. C. Pitcher, D. R. Walker, B. A. Mitchell-Innes \\ Sea Fisheries Research Institute, Private Bag X2, Rogge Bay 8012, Cape Town, South Africa
}

\begin{abstract}
Sinking rates of phytoplankton assemblages with diverse and variable taxonomic composition, growing under a variety of environmental conditions, were measured in St. Helena Bay (S. Africa) using the homogenous sample method SETCOL. These measurements and flux estimates from sediment trap recoveries enabled the role of sinking phytoplankton in the flux of organic material from the euphotic zone to be determined. Sinking rates were found to be influenced by the duration of the settling experiments. Chlorophyll a sinking rates ranged from 0 to $0.91 \mathrm{~m} \mathrm{~d}^{-1}$ but were poorly correlated to phytoplankton carbon sinking rates which ranged from 0 to $0.78 \mathrm{~m} \mathrm{~d}^{-1}$ Sinking rates of phytoplankton populations were significantly correlated not to any of the environmental parameters measured but to taxonomic properties of the assemblages, which were in turn governed by prevailing environmental conditions. Phytoplankton carbon flux estimates, made from both the SETCOL measurements and the sediment trap recoveries, were in general agreement and did not exceed $6.1 \%$ of primary production. Losses from the euphotic zone during the study period resulting from the sinking of intact phytoplankton were therefore of limited importance to the time-dependent changes of phytoplankton biomass. Phytoplankton sinking was, however, considered to have an impact on phytoplankton composition due to the variable sinking rates of the different assemblage components.
\end{abstract}

\section{INTRODUCTION}

The success of a phytoplankton population largely depends on its ability to strike a favourable balance between rates of cell division, grazing losses and sinking. Phytoplankton generally have a specific weight exceeding that of seawater, and therefore sink from the euphotic zone. Sinking rates are influenced by a number of factors, including various forms of motility, cellular morphology, physiological state, density and viscosity of the medium, and local water movements. The physiological mechanisms responsible for the regulation of phytoplankton buoyancy are intimately tied to growth processes, which are in turn determined largely by ambient light intensity and the prevailing and/or preconditioning nutrient regime. The degree to which the above factors influence the sinking rates of phytoplankton assemblages remains uncertain (Johnson \& Smith 1986).

Algae which sink from the euphotic zone represent a loss from the population. Therefore sinking may influence the successional patterns of various species and size classes of phytoplankton, as well as the vertical distribution of phytoplankton biomass and production (Bienfang et al. 1982). The effects of sinking on the vertical transfer of biomass account for its importance in many models of primary production (Bienfang 1981a). An analysis of sinking rates of different phytoplankton assemblages, under a variety of environmental conditions, may therefore lead to a further understanding of the dynamics of phytoplankton assemblages.

A preliminary carbon budget of the southern Benguela upwelling system by Bergh et al. (1985) quantified reasonably well the growth processes of phytoplankton, but loss processes were poorly quantified by unknown grazing and sinking terms. These authors estimated the consumption requirements of zooplankton and pelagic fish to be $25 \%$ of the phytoplankton production, leaving $75 \%$ to form detritus, which they suggested is either decomposed in the water column or is exported to be deposited on the sea floor. The purpose of this study was to estimate sinking rates of phytoplankton in St. Helena Bay (S. Africa), an area of enhanced primary production within the Benguela upwelling system (Bailey 1985), and to attempt to relate these rates to spatial and temporal variability in environmental parameters. Thereby, the role of passive sinking of phytoplankton in the flux of organic material from the euphotic zone could be determined. 


\section{METHODS AND MATERIALS}

The RS 'Benguela' was anchored in $47 \mathrm{~m}$ of water in St. Helena Bay $\left(32^{\circ} 33.2^{\prime} \mathrm{S} ; 1^{\circ} 05.2^{\prime} \mathrm{E}\right)$ from 19 March to 15 April 1987, providing a platform for the collection of a time series of data. During the final $10 \mathrm{~d}$ of the anchor station study (6 to 15 April), sinking rate determinations were conducted each day, on samples collected from the surface, the thermocline region and the bottom mixed layer (Fig. 1). Water samples were collected at midday using a rosette sampler. Continuous temperature readings were obtained with a Neil Brown Mark III CTD bathysonde. Light attenuation was measured using an underwater quantum sensor attached to the rosette sampler. Samples for analysis of nitrate and chlorophyll a were taken from selected depths every $4 \mathrm{~h}$. Nitrate samples were analysed on board according to Mostert (1983) and chlorophyll a samples were analysed by spectrophotometric analysis (SCOR Working Group 17 1966). In situ primary production meas- urements were made daily using the ${ }^{14} \mathrm{C}$ technique as described by Mitchell-Innes \& Walker (unpubl.).

Sinking rates were measured using the homogenous sample method SETCOL, a simple technique suitable for determining the sinking rate of phytoplankton populations (Bienfang 1981a). The method enables the sinking rates of various parameters of particulate matter to be determined. The procedure involves the use of settling columns initially containing a uniformly mixed population of cells. A mean sinking rate is calculated. based upon the net change in the vertical distribution of cells after a given time. The calculated sinking rate is therefore a function of the settled fraction of the phytoplankton population in the lower portion of the column relative to the initial population within the column, as well as the length of the column and the settling interval, according to the formula:

$$
\psi=\mathrm{f}_{\mathrm{s}} \cdot \mathrm{l} / \mathrm{t}
$$

where $\psi=$ sinking rate $f_{s}=$ settled fraction of popula-

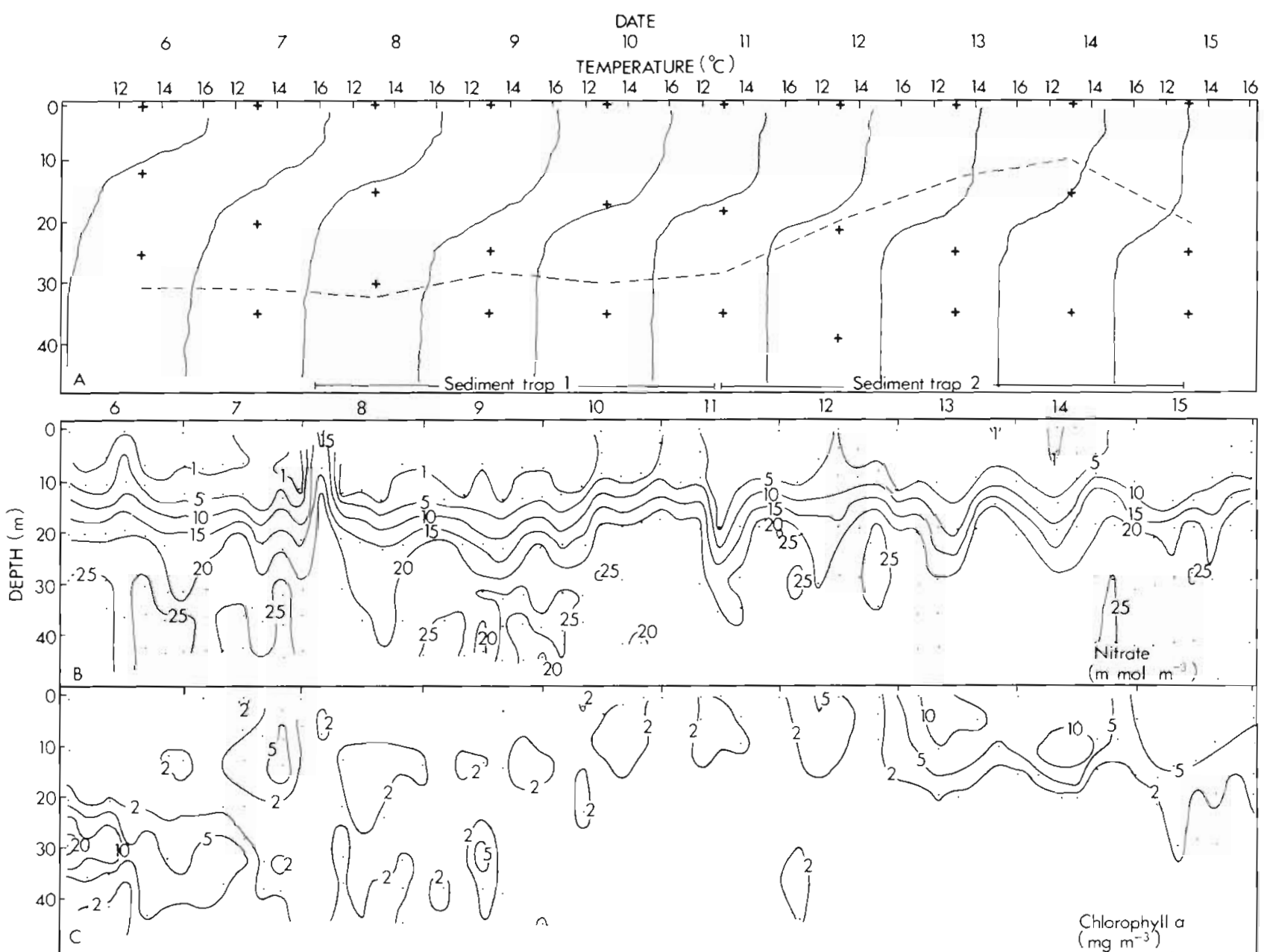

Fig. 1. (A) Temperature profiles of the water column at midday. Samples for sinking rate determinations were collected $(+)$ from surface, thermocline and bottom mixed layer. Broken line denotes depth of $1 \%$ light level. Vertical profiles of (B) nitrate concentrations and (C) chlorophyll a concentrations from 6 to 15 April at the anchor station 
tion; $l=$ length of column; $\mathrm{t}=$ settling interval. Water samples were collected from 3 depths each day and immediately transported to a land-based laboratory. Here 4 settling columns were filled with water collected from each of the sampling depths. For 3 of the columns, the parameter analysed was chlorophyll $a$, which was determined fluorometrically according to the methods outlined in Parsons et al. (1984). For the remaining column the parameter determined was phytoplankton carbon. Samples were fixed in $4 \%$ boratebuffered formalin and cells were enumerated on an inverted microscope according to Utermöhl as described by Hasle (1978). Many cells were identified to species; however, some could be assigned only to a genus or more vaguely defined group. For example, most naked nanoplankton were categorized according to size ( 2 to $6 \mu \mathrm{m}$ and 7 to $12 \mu \mathrm{m}$ ) under the general heading of microflagellates. Phytoplankton cell volumes were determined from cell dimensions, and phytoplankton carbon (PPC) was calculated using the equations of Strathmann (1967) as modified by Eppley et al. (1970).

Most SETCOL experiments were run for periods of $6 \mathrm{~h}$. Experiments were, however, also conducted to determine the effects of the duration of settling on the calculated sinking rates. On 3 selected days $(9,12$ and 15 April) the time allowed for settling was 2, 4 and $6 \mathrm{~h}$ and chlorophyll a was used as an index of biomass.

Phytoplankton carbon flux estimates were provided by the product of the SETCOL sinking rates and the mean phytoplankton carbon concentrations within the euphotic zone. Surface sinking rates were used for these calculations as they were believed to be most representative of the sinking rates of the phytoplankton assemblages dominating the water column. Mean phytoplankton carbon concentrations within the euphotic zone were calculated from the chlorophyll a data, using a PPC : chl a ratio of $62: 1$, determined from regression analysis of PPC and chl $a(y=0.016 x-0.51$; $\left.F=153.3, r^{2}=0.85, p \ll 0.05\right)$.

Sediment traps, similar to those described by Knauer et al. (1979), were suspended below the thermocline at $39 \mathrm{~m}$. The traps were filled with a $5 \%$ formalin-saturated solution of $\mathrm{NaCl}$ and were deployed for 2 periods of ca $4 \mathrm{~d}$ each ( 7 to 11 and 11 to 15 April). Recoveries from these traps provided further estimates of flux. Subsamples were taken from the traps for enumeration of phytoplankton cells and estimation of phytoplankton carbon

The above 2 methods of estimating PPC flux enabled the determination of 2 separate estimates of the percentage primary production sinking from the euphotic zone. The 2 methods, however, differed with respect to the effects of turbulence. The SETCOL method dealt with microparticulates under hydrostatic conditions, whereas the sediment trap approach incorporated the effects of water motion.

\section{RESULTS AND DISCUSSION}

\section{Physical, chemical and biological environment}

Details of the physical and chemical environment during the anchor station study are given by Bailey \& Chapman (unpubl.). The final $10 \mathrm{~d}$ of the study can generally be divided into 2 periods with regard to the physical, chemical and biological environments, which corresponded to the 2 periods of sediment trap deployment (Fig. 1).

The initial period ( 6 to 11 April) was characterized by warm, stable surface waters $\left(14.75\right.$ to $\left.16.64^{\circ} \mathrm{C}\right)$, with high oxygen ( 5.55 to $\left.7.63 \mathrm{ml} \mathrm{l}^{-1}\right)$, low chlorophyll a $(0.3$ to $5.2 \mathrm{mg} \mathrm{m}^{-3}$ ), low nutrient concentrations (nitrate: 0.3 to $4.7 \mathrm{mmol} \mathrm{m}^{-3}$ ) and a 28 to $33 \mathrm{~m}$ deep euphotic zone. The second period (11 to 15 April) was characterized by the introduction of colder, recently upwelled, wellmixed surface waters $\left(12.86\right.$ to $\left.15.72{ }^{\circ} \mathrm{C}\right)$, with lower oxygen (4.53 to $\left.7.01 \mathrm{mll}^{-1}\right)$, higher chlorophyll a $(0.1$ to $18.8 \mathrm{mg} \mathrm{m}^{-3}$ ), higher nutrient concentrations (nitrate: 0.6 to $9.3 \mathrm{mmol} \mathrm{m}^{-3}$ ) and a 10 to $28 \mathrm{~m}$ deep euphotic zone.

These 2 periods were also evident upon examining the phytoplankton production, biomass and composition (Fig. 2). The initial period was characterized by low production, low biomass and was dominated by microflagellates in terms of carbon. Microflagellate concentrations were greatest at the surface on 10 April and exceeded $18 \times 10^{6}$ cells $1^{-1}$. The most common microflagellate species belonged to the genera Chrysochromulina and Imantonia. The second period was characterized by higher production, higher biomass and was dominated by diatoms in terms of carbon. The diatom bloom during this period was dominated by Bacteriastrum delicatulum which was recorded at concentrations of $1.5 \times 10^{6}$ cells $1^{-1}$ at the surface on 15 April.

The anchor station therefore provided an experimental framework to monitor sinking rates of mixed phytoplankton assemblages with diverse and variable taxonomic composition, growing under a variety of environmental conditions.

\section{Sinking rates}

The duration of the SETCOL experiments exhibited a variable and often marked effect on the calculated sinking rates of chlorophyll a (Fig. 3). The settled biomass fraction $\left(\mathrm{f}_{\mathrm{s}}\right)$ increased approximately linearly with 


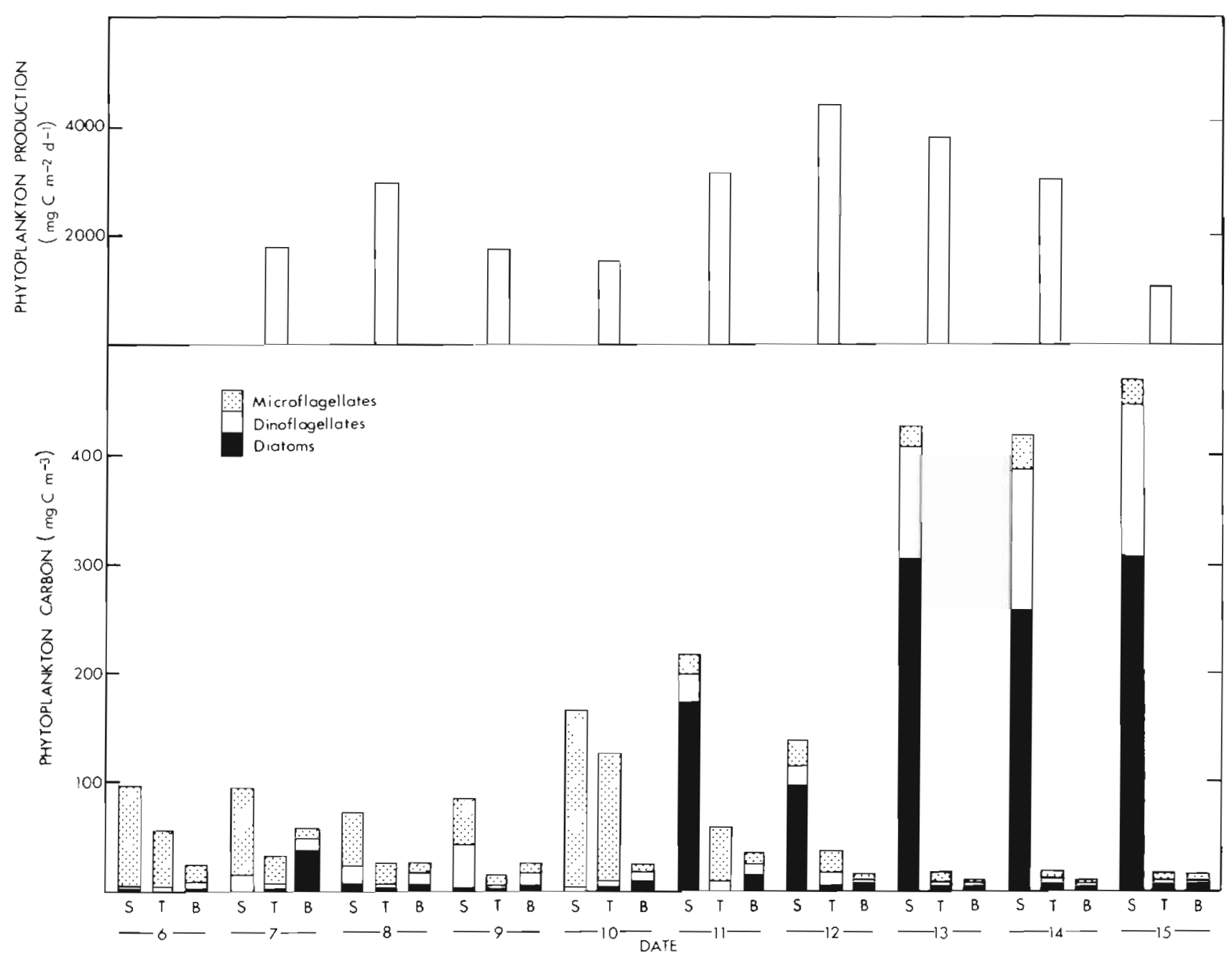

Fig. 2. Phytoplankton production rates integrated to the bottom of the euphotic zone, and phytoplankton carbon composition at surface (S), thermocline (T) and bottom mixed layer (B) from 6 to 15 April

time for trials on water samples collected at the surface. Thus for these particular cases the duration of the experiments had a limited influence on the calculated sinking rates. However, for most samples collected at the thermocline and bottom mixed layer a curvilinear increase in the settled biomass fraction was found with an increase in the duration of the experiment. Thus experiments with shorter settling times invariably resulted in higher sinking rates.

Bienfang (1981a) found that the settled biomass fraction increased in a linear fashion, until most of the biomass reached the bottom of the column. Therefore the duration of settling according to Bienfang (1981a) would not influence calculated sinking rates, provided trials were not run over sufficient duration to allow the settled fraction of the population to attain unity, as such occurrence would yield an underestimate of the true sinking rate of the sample. Johnson \& Smith (1986) agreed that this may be true for unialgal cultures. However, in natural systems with heterogeneous phytoplankton assemblages, differences in the sinking rates of the various particulates may result in differences in the calculated mean sinking rate of the assemblage, depending on the duration of the experiment. Shorter settling times thus measure primarily the faster sinking fraction of the particulates, whereas longer settling times give lower sinking rates, which result from the cumulative impact of slower sinking particles. Johnson \& Smith (1986) therefore suggested that the settled biomass fraction may be a hyperbolic function of the duration of settling.

Such a relationship was evident in this study. The curvilinear increase in the settled biomass fraction of samples collected from the thermocline and bottom mixed layer most likely resulted from the increased presence of large rapidly sinking particles at these depths. On 15 April the settled biomass fraction of the 


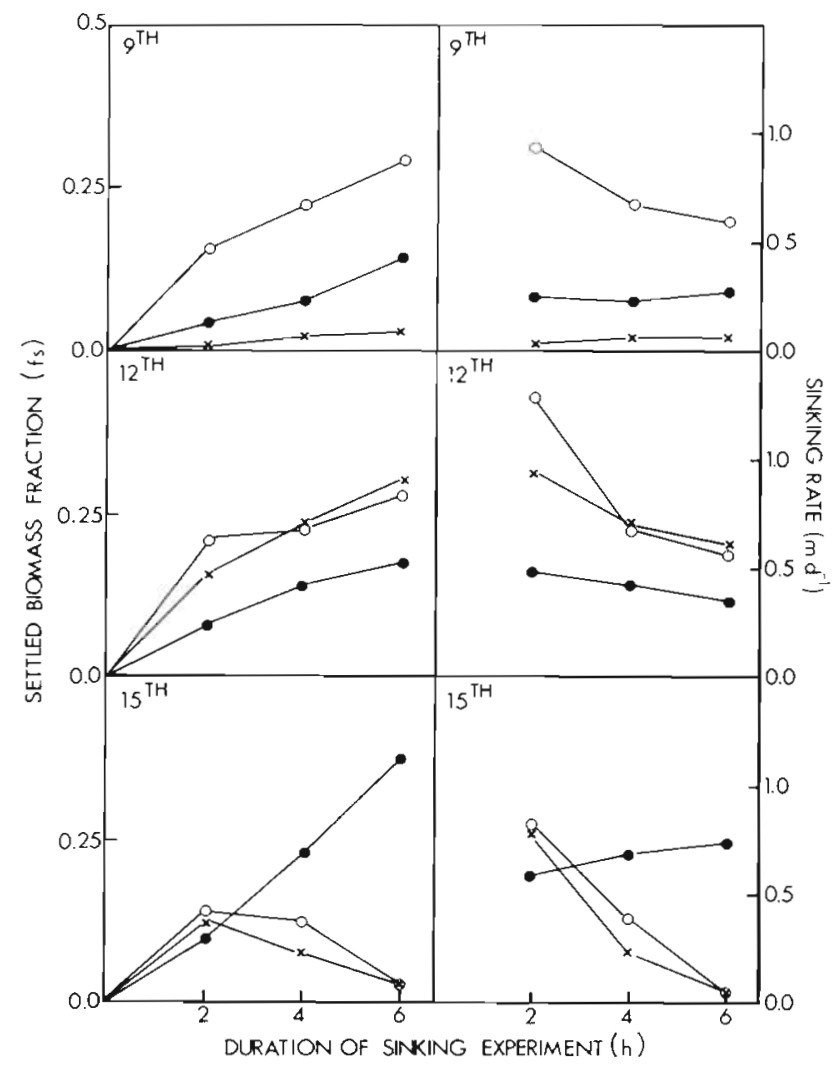

Fig. 3. Relationship between the settled biomass fraction (chlorophyll $a, f_{s}$ ) and the resulting sinking rate vs the duration of the experiment, for samples collected at surface ( $\bullet$ ), thermo-

cline $(x)$ and bottom mixed layer (o), on 3 selected days

samples from the thermocline and bottom mixed layer decreased with an increase in the duration of the experiment, possibly as a result of the upward migration of certain particulates after the initial rapid sinking of the larger particles.

The above results indicate that when using the SETCOL method to measure sinking rates of natural assemblages, the duration of settling is most important since it can influence the rates measured. For the remainder of the results presented in this paper, the SETCOL experiments were run for $6 \mathrm{~h}$ periods.

Sinking rates were found to be dependent on the parameter measured. Similar ranges were found for both the chlorophyll a and phytoplankton carbon sinking rates, which varied from day to day and also with sampling depth. Chlorophyll a sinking rates ranged from 0 to $0.91 \mathrm{~m} \mathrm{~d}^{-1}$ (Table 1 ) and phytoplankton carbon sinking rates from 0 to $0.78 \mathrm{md}^{-1}$ (Table 2). Although chlorophyll a sinking rates were often similar to phytoplankton carbon sinking rates (Fig. 4), they were not significantly correlated $(p>0.05)$, possibly due to the varying contribution of faecal pellets, detritus and other particulates to the chlorophyll a concentrations. This poor correlation would suggest that chlorophyll a sinking rates, when used as an indication of phytoplankton sinking rates, should be used with considerable caution. Therefore for the remainder of this discussion only the phytoplankton carbon sinking rates will be considered.

Observed sinking rates of natural populations reflect the net buoyancy responses to a number of environmental parameters, such as temperature, light and nutrients. The simultaneous variation of these potentially influential factors, together with co-occurring changes in the population size structure and species composition throughout the study, make it difficult to isolate the individual effects of each of these parameters on the observed sinking rate variations.

During the anchor station study, phytoplankton carbon sinking rates were not significantly correlated $(p>0.05)$ to any of the environmental parameters measured. Bienfang (1982) suggested that the absence of statistically significant correlation between the phytoplankton sinking rate and the prevailing temperature, light or nutrient conditions may be related to lags between environmental variations and the accompanying physiological responses associated with modifications of cell density. Therefore the preconditioning history of the population may be more closely associ-

Table 1. Mean chlorophyll a sinking rates determined from samples collected at the surface, thermocline and bottom mixed layer from 6 to 15 April 1987. nd: non-detectable sinking rates; numbers in parentheses: range of 3 SETCOL measurements; absence indicates only 1 measurement

\begin{tabular}{|lccccccccccc}
\hline $\begin{array}{l}\text { Sampling } \\
\text { depth }\end{array}$ & 6 Apr & 7 Apr & 8 Apr & 9 Apr & 10 Apr & 11 Apr & 12 Apr & 13 Apr & 14 Apr & 15 Apr \\
\hline Surface & 0.10 & 0.26 & 0.22 & 0.28 & nd & 0.26 & 0.35 & 0.39 & 0.11 & 0.74 \\
& $(0.06-0.14)$ & $(0.18-0.33)$ & $(0.14-0.30)$ & - & - & $(0.23-0.29)$ & - & $(0.35-0.46)$ & $(0.02-0.19)$ & - \\
$\begin{array}{l}\text { Thermocline } \\
\text { region }\end{array}$ & 0.52 & 0.17 & 0.04 & 0.06 & 0.13 & 0.47 & 0.61 & 0.19 & 0.21 & 0.05 \\
$\begin{array}{l}\text { Bottom } \\
\text { mixed }\end{array}$ & $(0.43-0.65)$ & $(0.12-0.19)$ & $(0.02-0.05)$ & - & $(0.08-0.21)$ & $(0.36-0.58)$ & - & $(0.07-0.26)$ & $(0.14-0.29)$ & - \\
layer & 0.38 & 0.64 & 0.74 & 0.59 & 0.41 & 0.30 & 0.56 & 0.41 & 0.24 & 0.05 \\
\end{tabular}


Table 2. Phytoplankton carbon (PPC) sinking rates determined from samples collected at the surface, thermocline and bottom mixed layer from 6 to 15 April 1987. nd: non-detectable sinking rates

\begin{tabular}{|lcccccccccc}
\hline $\begin{array}{l}\text { Sampling } \\
\text { depth }\end{array}$ & 6 Apr & 7 Apr & 8 Apr & 9 Apr & 10 Apr & 11 Apr & 12 Apr & 13 Apr & 14 Apr & 15 Apr \\
\hline $\begin{array}{l}\text { Surface } \\
\begin{array}{l}\text { Thermocline } \\
\text { region }\end{array}\end{array}$ & 0.33 & 0.26 & nd & nd & nd & 0.33 & 0.42 & 0.48 & 0.35 & 0.36 \\
$\begin{array}{l}\text { Bottom mixed } \\
\text { layer }\end{array}$ & 0.08 & 0.12 & nd & 0.12 & nd & nd & 0.12 & 0.37 & 0.12 & 0.08 \\
\hline
\end{tabular}

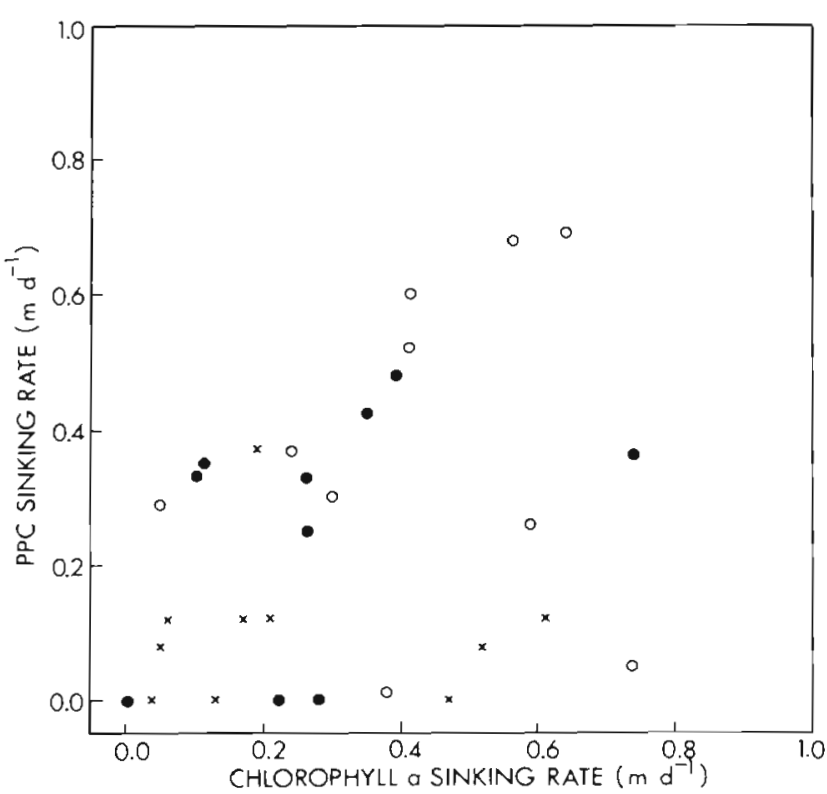

Fig. 4. Relationship between phytoplankton carbon (PPC) sinking rate and chlorophyll a sinking rate determined from samples collected from surface $(\bullet)$, thermocline $(x)$ and bottom mixed layer (0), from 6 to 15 April. The 2 sinking rates were not significantly correlated $\left(F=3.31, r^{2}=0.11, p>0.05\right)$

ated with population buoyancy modifications than the prevailing conditions at the time of a given experiment.

On examination of the sinking rates of certain components of the phytoplankton assemblages present during the anchor station, it was evident that there was considerable variation. Sinking rates of microflagellates $\left(2\right.$ to $6 \mu \mathrm{m}$ ) were usually $0 \mathrm{~m} \mathrm{~d}^{-1}$, whereas the sinking rate of the dominant diatom Bacteriastrum delicatulum varied from 0.29 to $0.59 \mathrm{~m} \mathrm{~d}^{-1}$ and the sinking rate of the large diatom Coscinodiscus gigas was calculated as $0.98 \mathrm{~m} \mathrm{~d}^{-1}$. It followed that the mean sinking rate of the assemblage would be determined to a large degree by the particular species dominating the assemblage in terms of carbon. It was therefore not surprising to find a statistically significant correlation $(p<0.05)$ between phytoplankton carbon sinking rates and the percentage diatom composition of the population in terms of carbon (Fig. 5). Thus, although sinking

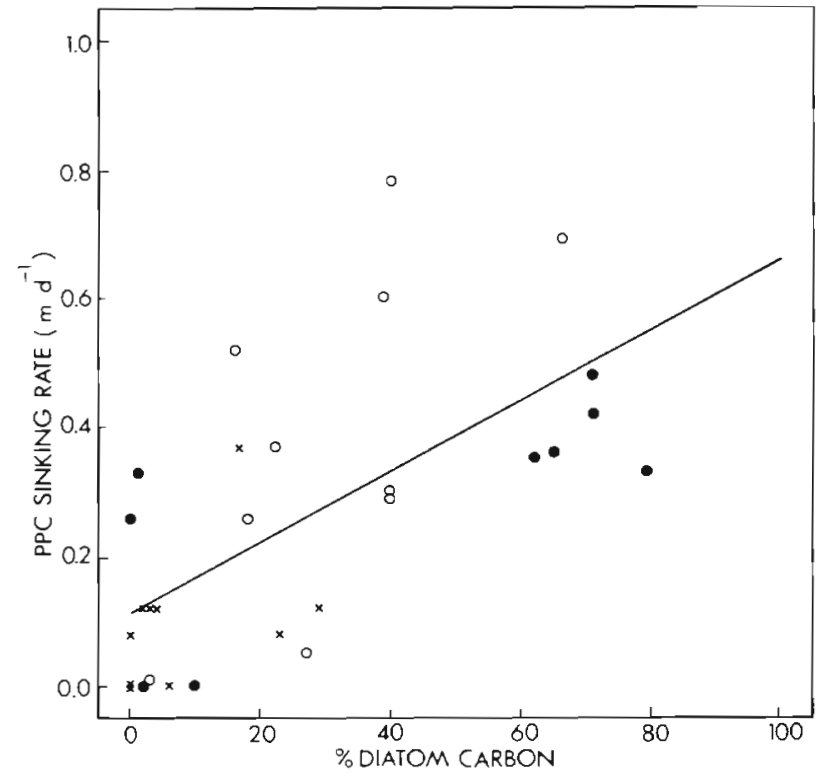

Fig. 5. Relationship between phytoplankton carbon (PPC) sinking rate and phytoplankton composition, expressed as percentage diatom carbon, determined from samples collected from surface $(\bullet)$, thermocline $(x)$ and bottom mixed layer (o), from 6 to 15 April. The 2 variables are significantly correlated: $y=0.0055 x+0.11\left(F=19.81, r^{2}=0.41, p \ll 0.05\right)$

rates were not correlated with any of the measured environmental parameters, they were found to be significantly correlated with the taxonomic properties of the assemblage itself. When the population was dominated by small, flagellated cells, low sinking rates were observed, whereas during diatom dominance, sinking rates tended to be higher.

With regard to the variation in phytoplankton carbon sinking rates with depth. (Table 2), sinking rates at the thermocline tended to be lower than those at the surface (paired t-test; $p<0.1$ ) or bottom mixed layer (paired t-test; $p<0.05$ ) for any given day. The decreased sinking rates at the thermocline may have resulted from elevated nutrient concentrations at these depths. Such sinking rate deceleration may play an important role in the development of subsurface chlorophyll a maxima, as suggested by Bienfang et al (1983). 
Table 3. Summary of phytoplankton production and phytoplankton carbon flux from the euphotic zone for the 2 periods of sediment trap deployment as determined by sediment trap and SETCOL experiments

\begin{tabular}{|c|c|c|c|c|c|c|c|}
\hline \multirow{2}{*}{$\begin{array}{l}\text { Period } \\
\text { of trap } \\
\text { deployment }\end{array}$} & \multirow{2}{*}{$\begin{array}{l}\text { Mean primary } \\
\text { production in } \\
\text { euphotic zone } \\
\left(\mathrm{mg} \mathrm{C} \mathrm{m} \mathrm{m}^{-2} \mathrm{~d}^{-1}\right)\end{array}$} & \multicolumn{2}{|c|}{ Sediment trap } & \multicolumn{4}{|c|}{ SETCOL experiments } \\
\hline & & $\begin{array}{c}\text { PPC flux } \\
\left(\mathrm{mg} \mathrm{Cm}^{-2}\right. \\
\left.\mathrm{d}^{-1}\right)\end{array}$ & $\begin{array}{l}\% \text { Primary } \\
\text { production } \\
\text { sinking from } \\
\text { euphotic zone }\end{array}$ & $\begin{array}{l}\text { Mean PPC } \\
\text { conc. in } \\
\text { euphotic zone } \\
\left(\mathrm{mg} \mathrm{C} \mathrm{m}^{-3}\right)\end{array}$ & $\begin{array}{c}\text { Mean surface } \\
\text { PPC sinking } \\
\text { rate } \\
\left(\mathrm{m} \mathrm{d}^{-1}\right)\end{array}$ & $\begin{array}{c}\text { PPC flux } \\
\text { (mg C m-2 } \\
\left.d^{-1}\right)\end{array}$ & $\begin{array}{l}\% \text { Primary } \\
\text { production } \\
\text { sinking from } \\
\text { euphotic zone }\end{array}$ \\
\hline 7-11 Apr & 2221 & 70 & 3.2 & 218 & 0.12 & 26 & 1.2 \\
\hline $11-15 \mathrm{Apr}$ & 3032 & 120 & 4.0 & 478 & 0.39 & 186 & 6.1 \\
\hline
\end{tabular}

\section{Flux estimates}

During the anchor station study, mean daily primary production integrated through the euphotic zone for the 2 periods of sediment trap deployment was 2221 and $3032 \mathrm{mg} \mathrm{C} \mathrm{m} \mathrm{m}^{-2} \mathrm{~d}^{-1}$ respectively. Phytoplankton carbon flux, determined from the analysis of material recovered from the sediment traps, was $70 \mathrm{mg} \mathrm{C}$ $\mathrm{m}^{-2} \mathrm{~d}^{-1}$ for the first period of deployment and $120 \mathrm{mg} \mathrm{C}$ $\mathrm{m}^{-2} \mathrm{~d}^{-1}$ for the second period. Therefore $3.2 \%$ and $4.0 \%$ of the primary production was lost through sedimentation for the first and second periods of deployment respectively (Table 3 ). The diatoms, as a result of their higher sinking rates, formed a disproportionately large fraction of the entrapped phytoplankton in terms of carbon; $95.0 \%$ for the first and $83.5 \%$ for the second period of deployment. The greater flux therefore occurred during the second period of trap deployment, due to the dominance of diatoms in the water column during this period.

Phytoplankton carbon flux estimates for the 2 periods of trap deployment were also determined by the product of the mean surface SETCOL sinking rates, and the mean phytoplankton carbon concentrations integrated through the euphotic zone. Such estimates must be viewed as extremely crude flux approximations as these rates vary in space and time and represent sinking in the absence of turbulence. However, the calculation does characterise the role which passive sinking may play relative to other processes, in the turnover of microparticulates within the euphotic zone. The mean surface sinking rate of $0.12 \mathrm{~m} \mathrm{~d}^{-1}$, for the initial period of trap deployment, when the surface assemblages were dominated by microflagellates, was significantly less ( $t$-test; $p<0.05$ ) than the mean surface sinking rate of $0.39 \mathrm{~m} \mathrm{~d}^{-1}$ for the latter period of trap deployment, when the surface populations were dominated by diatoms in terms of carbon. The calculated phytoplankton carbon flux values were 26 and $186 \mathrm{mg} \mathrm{C} \mathrm{m}^{-2} \mathrm{~d}^{-1}$ respectively, for the 2 periods of deployment. Therefore, despite the problems of extrapolating these sinking rate measurements to estimates of phytoplankton carbon flux, the values of $1.2 \%$ and $6.1 \%$ of the pri- mary production lost through sedimentation, for the first and second periods of trap deployment respectively, were relatively low as were the estimates provided by the sediment traps (Table 3).

\section{CONCLUSIONS}

These observations represent the first phytoplankton sinking rates reported from the southern Benguela region. The sinking rates determined using the SETCOL method were found to be influenced by the duration of the settling experiments. Although this influence was small for the surface samples, had the experiments for the thermocline and bottom mixed layer samples been run for shorter periods, considerably higher sinking rates would have been calculated for these depths. Chlorophyll a sinking rates were found to be a poor indication of phytoplankton sinking rates and provided no information on the sinking of various components of the assemblage. Although the determination of phytoplankton carbon sinking rates is more time consuming, these are most definitely more informative and reliable. Many previous studies of this nature have used the SETCOL method to determine sinking rates; some fail to mention the duration of settling and most have used chlorophyll as an indication of phytoplankton sinking rates.

Despite these differences, the sinking rates observed during this investigation are remarkably similar to those reported in recent studies. Bienfang (1985) found the sinking rates of chlorophyll in well-stratified, nutrient-depleted subtropical waters dominated by smallcelled phytoplankton to average $0.06 \mathrm{~m} \mathrm{~d}^{-1}$. Bienfang \& Harrison (1984) examined a diatom-dominated temperate assemblage consisting primarily of large-celled and long-chained diatoms and found the sinking rates of chlorophyll to average $0.96 \mathrm{~m} \mathrm{~d}^{-1}$. Bienfang (1984) monitored the sinking rates of microparticulate material collected from Resurrection Bay, a subarctic ecosystem. During summer when stratification restricted the vertical nutrient supply, low nutrient concentrations favoured the presence of small flagellates, pennate diatoms and coccolithophorids. During this 
period, the average sinking rate for chlorophyll was $0.07 \mathrm{~m} \mathrm{~d}^{-1}$, whereas for the spring bloom assemblage, when large centric and pennate diatoms dominated. the sinking rate of chlorophyll averaged $0.43 \mathrm{~m} \mathrm{~d}^{-1}$. Sinking rates of chlorophyll in subantarctic waters were reported by Jacques \& Hoepffner (1984) to range from 0.1 to $0.52 \mathrm{~m} \mathrm{~d}^{-1}$. These studies, like the present study, tend to suggest that sinking rates of natural phytoplankton assemblages are determined primarily by their composition, which is governed by the prevailing environmental conditions, rather than the prevailing physiological state of the population.

Since the studies of Steele \& Yentsch (1960), phytoplankton sinking rates have been considered to be closely related to nutrient concentration, as experimental studies on single species found nutrient limitation to result in elevated sinking rates. This has resulted in a number of modelling attempts which have incorporated modifications in sinking rates due to changes in ambient nutrient levels (Bienfang et al. 1982). However, studies of natural heterogeneous phytoplankton populations have revealed no correlation between ambient nutrient levels and sinking rates (Bienfang 1981b). This study has found, as Lännergren (1979) suggested, that the proposed relationship between nutrient concentration and sinking rate may be reversed, due to changes in the species assemblage, associated with changes in the nutrient regime. During the initial period of this study the warm stable surface waters and low nutrient conditions favoured the presence of microflagellates, during which low sinking rates were observed, whereas during high nutrient concentrations following upwelling, diatoms were found to dominate resulting in higher sinking rates. Variation of phytoplankton sinking rates was therefore mainly attributed to shifts in the population size distribution and taxonomic composition, although increased nutrient concentrations at the thermocline may have resulted in reduced sinking in this region.

During this study, losses from the euphotic zone, resulting from the sinking of intact phytoplankton, were of limited importance to the time-dependent changes of phytoplankton biomass. Estimates from sediment trap recoveries earlier during the anchor station study indicated a maximum of $13.8 \%$ of the primary production sinking from the euphotic zone (unpubl.). These estimates were therefore also in general agreement with those of other recent investigations. Bienfang (1985) indicated that sedimentation accounted for about $7 \%$ of the daily photosynthetic carbon production in oligotrophic subtropical waters and Bienfang (1984) estimated the total downward flux of carbon to be $13 \%$ of daily primary production in Resurrection Bay, Alaska. Despite the apparent limited importance of sinking in determining phytoplankton biomass, the passive sinking of phytoplankton may well have a significant impact on the composition of the phytoplankton assemblages due to the variable sinking rates of the different components of the assemblages.

Acknowledgements. We thank Mr G. W. Bailey and Dr P. Chapman, and all other participants of the anchor station study, including the officers and crew of the RS 'Benguela' for making the above study possible. We also acknowledge the criticism and advice received from Drs L. Hutchings and J. J. Bolton on the manuscript.

\section{LITERATURE CITED}

Bailey, G. W. (1985). Distribution and cycling of nutrients at four sites in the Benguela system. In: Bas, C., Margalef, R., Rubies, P. (eds.) International symposium on the most important upwelling areas off Western Africa (Cape Blanco and Benguela). Instituto de Investigaciones Pesqueras, Barcelona, p. 305-317

Bergh, M. O. Field, J. G., Shannon, L. V (1985). A preliminary carbon budget of the southern Benguela pelagic ecosystem. In: Bas, C., Margalef, R., Rubies, P. (eds.) International symposium on the most important upwelling areas off Western Africa (Cape Blanco and Benguela). Instituto de Investigaciones Pesqueras, Barcelona, p. 281-304

Bienfang, P. K. (1981a). SETCOL - a technologically simple and reliable method for measuring phytoplankton sinking rates. Can. J. Fish. aquat. Sci. 38 (10): 1289-1294

Bienfang, P. K. (1981b). Sinking rates of heterogeneous, temperate phytoplankton populations. J. Plankton Res. 3 (2): 235-253

Bienfang, P. K. (1982). Phytoplankton sinking-rate dynamics in enclosed experimental ecosystems. In: Grice, G. D., Reeve, M. R. (eds.) Marine mesocosms. Biological and chemical research in experimental ecosystems. SpringerVerlag, New York, p. 261-274

Bienfang, P. K. (1984). Size structure and sedimentation of biogenic microparticulates in a subarctic ecosystem. J. Plankton Res. 6 (6): 985-995

Bienfang, P. K. (1985). Size structure and sinking rates of various microparticulate constituents in oligotrophic Hawaiian waters. Mar. Ecol. Prog. Ser 23: 143-151

Bienfang, P. K., Harrison, P. J. (1984). Sinking-rate response of natural assemblages of temperate and subtropical phytoplankton to nutrient depletion. Mar Biol. 83: 293-300

Bienfang, P. K., Harrison, P. J., Quarmby, L. M. (1982). Sinking rate response to depletion of nitrate, phosphate and silicate in four marine diatoms. Mar. Biol. 67: 295-302

Bienfang, P. K., Szyper, J. P., Laws, E. A. (1983). Sinking rate and pigment responses to light-limitation of a marne diatom. Implications to dynamics of chlorophyll maximum layers. Oceanological Acta 6 (1): 55-62

Eppley, R. W., Reid, F. M. H., Strickland, J. D. H. (1970). The ecology of the phytoplankton off La Jolla, California, in the period April through September 1967. In: Strickland, J. D. H (ed.) Estimates of phytoplankton crop size, growth rate and primary production. Bull. Scripps Inst. Oceanogr. 17: 33-42

Hasle, G. R. (1978). Settling, the inverted-microscope method In: Sournia, A. (ed.) Phytoplankton manual - monographs on oceanographic methodology, No.6. UNESCO, Paris, p. $88-96$

Jacques, G., Hoepfner, N. (1984). Sinking rates of subantarctic neritic phytoplankton. C. r. hebd. Séanc. Acad. Sci., Paris, Sér. IIl 299: 581-584 
Johnson, T O., Smith, W. O. (1986). Sinking rates of phytoplankton assemblages in the Weddell Sea marginal ice zone. Mar Ecol. Prog. Ser. 33: 131-137

Knauer, G. A., Martin, J. H., Bruland, K. W. (1979). Fluxes of particulate carbon, nitrogen and phosphorus in the upper water column of the northeast Pacific. Deep Sea Res. 26 : 97-108

Lännergren, C. (1979). Buoyancy of natural populations of marine phytoplankton. Mar. Biol. 54: 1-10

Mostert, S. A. (1983). Procedures used in South Africa for the automatic photometric determination of micronutrients in seawater S. Afr. J. mar Sci. 1: 189-198

This article was submitted to the editor
Parsons, T. R., Maita, Y., Lalli, C. M. (1984). A manual of chemical and biological methods for seawater analysis Pergamon Press, Oxford

SCOR Working Group 17 (1966). Determination of photosynthetic pigments. In: Determination of photosynthetic pigments in seawater - monographs on oceanographic methodology, No. 1 UNESCO, Paris, p. 9-18

Steele, J. H., Yentsch, C. S. (1960). The vertical distribution of chlorophyll. J. mar biol. Ass. U.K. 39: 217-226

Strathmann, R. R. (1967). Estimating the organic carbon content of phytoplankton from cell volume or plasma volume. Limnol. Oceanogr $12(3): 411-418$

Manuscript first received: January 23, 1989

Revised version accepted: April 30, 1989 